\title{
Comparison of the usefulness of miscanthus, spartina and Jerusalem artichoke for phytoremediation of soils contaminated with nickel
}

\section{Porównanie przydatności miskanta, spartiny i topinamburu do fitoremediacji gleb skażonych niklem}

\author{
Jolanta Korzeniowska*, Ewa Stanisławska-Glubiak, Aleksander Mickiewicz
}

\section{Summary}

The response of miscanthus (Miscanthus $\times$ giganteus), spartina (Spartina pectinata) and Jerusalem artichoke (Helianthus tuberosus) to nickel ( $\mathrm{Ni}$ ) excess in contaminated soil was tested in the two-year microplot experiment. The microplots, with a surface of $1 \mathrm{~m}^{2}$ and deep of $1 \mathrm{~m}$, were filled with sandy soil, artificially contaminated with nickel at the following doses: 0 (control without $\mathrm{Ni}$ ), $\mathrm{Ni}_{1}-60, \mathrm{Ni}_{2}-100$ and $\mathrm{Ni}_{3}-240 \mathrm{mg} / \mathrm{kg}$. Plant tolerance to nickel toxicity and their ability to $\mathrm{Ni}$ accumulation, and translocation were evaluated using a tolerance index (TI), bioaccumulation factors (BF) and translocation factor (TF). It was found that none of the tested species was suitable for phytoextraction nor showed high phytostabilization potential of nickel. Among the tested plants, spartina demonstrated the highest tolerance to $\mathrm{Ni}(70 \%)$, relatively high ability to $\mathrm{Ni}$ accumulation in the roots and limited transport of $\mathrm{Ni}$ from roots to aboveground parts.

Key words: soil contamination; Ni; phytostabilization; Miscanthus x giganteus; Spartina pectinata; Helianthus tuberosus

\section{Streszczenie}

W dwuletnim doświadczeniu mikropoletkowym testowano reakcję miskanta (Miscanthus $\times$ giganteus), spartiny (Spartina pectinata) i topinamburu (Helianthus tuberosus) na nadmiar Ni w glebie. Obetonowane mikropoletka o powierzchni $1 \mathrm{~m}^{2} \mathrm{i}$ głębokości

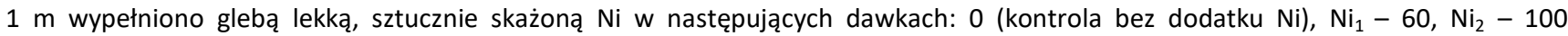
i $\mathrm{Ni}_{3}-240 \mathrm{mg} / \mathrm{kg}$. Tolerancję roślin na $\mathrm{Ni}$ oraz ich zdolność akumulacji i translokacji $\mathrm{Ni}$ w częściach podziemnych i nadziemnych oceniano przy pomocy indeksu tolerancji (TI), współczynników bioakumulacji (BF) oraz współczynnika translokacji (TF). Stwierdzono, że żaden z testowanych gatunków nie nadawał się do fitoekstrakcji Ni z gleby ani nie wykazał wysokiego potencjału fitostabilizacyjnego w stosunku do gleby skażonej Ni. Spośród badanych gatunków roślin spartina wykazała najwyższą tolerancję na Ni (70\%), stosunkowo dużą zdolność akumulacji Ni w korzeniach oraz ograniczony transport Ni do części nadziemnej.

Słowa kluczowe: zanieczyszczenie gleby; Ni; fitostabilizacja; Miscanthus x giganteus; Spartina pectinata; Helianthus tuberosus

*corresponding author: j.korzeniowska@iung.wroclaw.p 


\section{Wstęp / Introduction}

Nikiel (Ni), pomimo że w niewielkich ilościach niezbędny dla organizmów żywych, po przekroczeniu wartości tolerowanych jest toksyczny dla ludzi, zwierząt i roślin (Kabata-Pendias i Mukherjee 2007). Pierwiastek ten dostaje się do środowiska z wielu antropogenicznych źródeł, takich jak: spalanie paliw kopalnych, górnictwo, hutnictwo i przemysł naftowy oraz spalanie odpadów i osadów ściekowych (Gaj i wsp. 2007; Ahmad i Ashraf 2011).

Całkowita średnia zawartość Ni w glebie wynosi około $20 \mathrm{mg} / \mathrm{kg}$ (Kabata-Pendias i Mukherjee 2007), a dopuszczalny limit jest ustalony na poziomie $100 \mathrm{mg} / \mathrm{kg}$ (Rozporządzenie 2016; Toth i wsp. 2016). Zanieczyszczenie gleb Ni nie jest bardzo częste, jednak istnieją tereny, gdzie działalność człowieka doprowadziła do nadmiernej jego akumulacji. Dane literaturowe donoszą o wielu miejscach na świecie, gdzie wystąpiło przekroczenie dopuszczalnego limitu. Dla przykładu wysokie zawartości Ni w glebie, rzędu 1600-2150 mg/kg, odnotowano w pobliżu huty Sudbury w Kanadzie (Adamo i wsp. 2002; Narendrula i wsp. 2012), 303 mg/kg - przy hucie metali nieżelaznych Plodiv w Bułgarii (Bacon i Dinev 2005), 267 mg/kg - wokół kopalni miedzi i niklu Selebi Phikwe w Botswanie (Ngole i Ekosse 2012), 212 mg/kg na terenie dawnego składowiska osadów w Danii (Algreen i wsp. 2014) i 122 mg/kg - na terenach dawnej spalarni odpadów w Czechach (Kacálková i wsp. 2014).

Tereny zanieczyszczone $\mathrm{Ni}$ wymagają remediacji. Jedną z nowych, szybko rozwijających się technik remediacyjnych, wykorzystujących rośliny, jest fitoremediacja. Jej główne zalety to: brak negatywnych skutków dla struktury, aktywności biologicznej i urodzajności gleby oraz niższy koszt w porównaniu z metodami fizycznymi i chemicznymi (Mulligan i wsp. 2001; Ghosh i Singh 2005). Dwie najbardziej popularne techniki fitoremediacji to fitoekstrakcja i fitostabilizacja. Pierwsza polega na pobieraniu metalu z gleby przez rośliny, które włączają je do struktur tkankowych, a następnie usunięciu tych metali wraz z zebranym plonem biomasy. Fitostabilizacja natomiast wykorzystuje rośliny do unieruchomienia zanieczyszczenia/metalu w glebie, które są absorbowane i akumulowane przez korzenie, adsorbowane na korzeniach lub wytrącane w rizosferze (Stanislawska-Glubiak i wsp. 2012; Karczewska i wsp. 2013). Mobilność zanieczyszczeń zmniejsza się, co powoduje ograniczenie migracji do wód gruntowych i powietrza. Zmniejsza się również ich biodostępność, zapobiegając rozprzestrzenianiu się $\mathrm{w}$ łańcuchu żywieniowym. Rośliny stosowane w fitostabilizacji wpływają na ilość wody przesiąkającej przez glebę, minimalizując powstawanie niebezpiecznego odcieku. Ponadto zapobiegają erozji gleby, a tym samym rozprzestrzenianiu się toksycznego metalu w środowisku (Srivastava 2016; Thakur i wsp. 2016). W przypadku Ni groźna jest przede wszystkim erozja wietrzna. Ni jest szczególnie niebezpieczny, gdy dostaje się do organizmu drogą wziewną jako pył (WHO 2000). Wdychanie Ni toksycznie oddziałuje na drogi oddechowe i układ odpornościowy. Istnieją bezsprzeczne dowody, że ekspozycja ludzi i zwierząt na niektóre związki niklu może powodować raka płuc (Tokar i wsp. 2011).
Toksyczność Ni dla roślin objawia się obniżeniem siły kiełkowania (Yusuf i wsp. 2011), ograniczeniem wzrostu i rozgałęziania korzeni (Seregin i wsp. 2003), zmniejszeniem pobierania składników pokarmowych (Ahmad i Ashraf 2011), uszkodzeniem aparatu fotosyntetycznego (Shafeeq i wsp. 2012) oraz wywołaniem stresu oksydacyjnego (Ali i wsp. 2003). Wszystkie te negatywne procesy skutkują znaczną redukcją plonu roślin.

Mała tolerancja większości roślin na nadmiar Ni ogranicza możliwość stosowania technik fitoremediacyjnych, a poszukiwanie gatunków, nadających się do jego ekstrakcji lub stabilizacji w glebie jest zagadnieniem o dużym znaczeniu praktycznym. Przydatność roślin do fitoremediacji metalu ocenia się na podstawie kilku parametrów, takich jak: (i) tolerancja roślin na metal związana $\mathrm{z}$ osiąganiem przez nie odpowiednio wysokiego plonu, (ii) gromadzenie metalu w częściach nadziemnych i podziemnych mierzona współczynnikiem bioakumulacji $\left(\mathrm{BF}_{\text {nad }}\right.$ i $\left.\mathrm{BF}_{\text {pod }}\right)$ oraz (iii) transfer metalu z korzeni do części nadziemnych mierzony współczynnikiem translokacji (TF) (Raskin i Ensley 2000).

BF (zwany też BAF lub BCF) jest definiowany jako stosunek zawartości metalu w częściach nadziemnych lub podziemnych roślin do zawartości metalu w glebie, podczas gdy TF jako stosunek zawartości metalu w częściach nadziemnych do zawartości w częściach podziemnych (Melo i wsp. 2009; Masarovicova i wsp. 2010; Stanislawska-Glubiak i wsp. 2015; Antonkiewicz i wsp. 2016; Golda i Korzeniowska 2016). Rośliny o wysokiej biomasie i wysokiej bioakumulacji w częściach nadziemnych $\left(\mathrm{BF}_{\text {nad }}>1\right)$ nadają się do fitoekstrakcji (McGrath i Zhao 2003; Cheraghi i wsp. 2011), podczas gdy rośliny o wysokim współczynniku bioakumulacji dla części podziemnych $\left(\mathrm{BF}_{\mathrm{pod}}>1\right)$ i jednocześnie niskim współczynniku translokacji $(\mathrm{TF}<1)$ są odpowiednie do fitostabilizacji (Roccotiello i wsp. 2010; Cheraghi i wsp. 2011).

Bardzo korzystnym rozwiązaniem jest użycie do fitoremediacji roślin uprawianych na cele energetyczne (Al Chami i wsp. 2015). Uprawa tego typu roślin na terenach zanieczyszczonych metalami może służyć zarówno rekultywacji gleby, jak i produkcji biomasy na cele energetyczne. W związku z tym, ważnym zagadnieniem jest określenie tolerancji popularnych roślin energetycznych na nadmiar Ni w glebie oraz zbadanie zdolności akumulacji i przemieszczania się Ni z części podziemnych do części nadziemnych tych roślin.

Celem przeprowadzonych badań była ocena przydatności miskanta (Miscanthus $\times$ giganteus), spartiny (Spartina pectinata) i topinamburu (Helianthus tuberosus) do fitoremediacji gleby zanieczyszczonej $\mathrm{Ni}$ w warunkach zbliżonych do polowych.

\section{Materiały i metody / Materials and methods}

\section{Eksperyment mikropoletkowy}

W Stacji Doświadczalnej Instytutu Uprawy Nawożenia i Gleboznawstwa - Państwowego Instytutu Badawczego (IUNG - PIB) w Baborówku koło Poznania, w latach 2009-2010 przeprowadzono dwuletnie doświadczenie mikropoletkowe, w którym testowano reakcję trzech roślin 
energetycznych na nadmiar $\mathrm{Ni}$ w glebie. Obetonowane mikropoletka (48 sztuk) o powierzchni $1 \mathrm{~m}^{2}$ i głębokości $1 \mathrm{~m}$ (bez dna), usytuowane na otwartej przestrzeni, wypełniono glebą przywiezioną $\mathrm{z}$ pola o składzie granulometrycznym piasku gliniastego lekkiego (tab. 1).

Tabela 1. Charakterystyka gleby doświadczalnej

Table 1. Characteristic of experimental soil

\begin{tabular}{l|c}
\hline \multicolumn{1}{c|}{ Cecha - Feature } & Wartość - Value \\
\hline Frakcja - Fraction 0,1-0,02 mm [\%] & 24 \\
\hline Frakcja - Fraction $<0,02 \mathrm{~mm} \mathrm{[ \% ]}$ & 16 \\
\hline $\mathrm{pH} \mathrm{KCl}$ & 5,6 \\
\hline $\mathrm{C}$ org. [\%] & 0,8 \\
\hline $\mathrm{P}^{1}[\mathrm{mg} / \mathrm{kg}]$ & 85 \\
\hline $\mathrm{K}^{1}[\mathrm{mg} / \mathrm{kg}]$ & 116 \\
\hline $\mathrm{Mg}^{2}[\mathrm{mg} / \mathrm{kg}]$ & 51 \\
\hline $\mathrm{Ni}^{3}[\mathrm{mg} / \mathrm{kg}]$ & 7,6 \\
\hline
\end{tabular}

${ }^{1}$ Egner, ${ }^{2}$ Schachtschabel, ${ }^{3}$ woda królewska - aqua regia

Gleba w mikropoletkach została sztucznie skażona Ni na 3 lata przed posadzeniem roślin testowych w następujących dawkach: 0 (kontrola bez dodatku $\mathrm{Ni}$ ), $\mathrm{Ni}_{1}-60, \mathrm{Ni}_{2}-100 \mathrm{i} \mathrm{Ni} \mathrm{N}_{3}-240 \mathrm{mg} / \mathrm{kg}$. Nikiel w formie siedmiowodnego siarczanu cynku (20,9\% Ni) rozpuszczono w wodzie i zaaplikowano na mikropoletka za pomocy konewki. Wprowadzono go najpierw do warstwy 15-30 cm i wymieszano z glebą, a następnie do warstwy 0-15 cm i również starannie wymieszano. Po aplikacji Ni, jesienią, posiano gorczycę jako roślinę wyrównawczą.

Sadzonki miskanta i spartiny oraz bulwy topinamburu wysadzono wiosną 2009 roku, początkowo w zwiększonej dwukrotnie obsadzie, a po kilku tygodniach dokonano przerywki, pozostawiając na poletku po 2 rośliny miskanta i spartiny oraz po 5 roślin topinamburu. W obu latach badań stosowano wiosną nawożenie podstawowe NPK w dawce odpowiednio $10: 2$ : $8 \mathrm{~g}$ na poletko. Mikropoletka były odchwaszczane ręcznie, a w okresach braku wystarczającej ilości opadów podlewane. W pierwszym roku badań zebrano tylko jeden pokos, a w drugim roku dwa pokosy roślin. Trawy zawsze zbierano w fazie początku kłoszenia. Topinambur $\mathrm{w}$ pierwszym roku zbierano $\mathrm{w}$ fazie początku kwitnienia, a w drugim roku $\mathrm{w}$ fazie początku kwitnienia oraz $\mathrm{w}$ fazie zawiązywania koszyczków. W drugim roku, przy zbiorze drugiego pokosu, określano również plon korzeni traw i bulw topinamburu.

Podczas zbioru roślin pobierano próbki roślin i gleby do analiz chemicznych. Wszystkie próbki roślinne starannie płukano (szczególnie korzenie), suszono w temperaturze $60^{\circ} \mathrm{C}$ i mielono. Próbki glebowe suszono w temperaturze pokojowej, a następnie przesiewano przez sito o średnicy oczek $2 \mathrm{~mm}$.

\section{Wyliczenie indeksu tolerancji oraz wspólczynników akumulacji i translokacji}

Tolerancję badanych roślin na nadmiar Ni porównywano wykorzystując indeks tolerancji oznaczony jako TI. Indeks wyliczono jako stosunek plonu biomasy na obiektach skażonych do biomasy na obiekcie kontrolnym według formuły:

$$
\mathrm{TI}=\frac{\text { średni plon z } 3 \text { dawek } \mathrm{Ni}\left[\mathrm{g} / \mathrm{cm}^{2}\right]}{\text { plon kontrolny }\left[\mathrm{g} / \mathrm{cm}^{2}\right]} \times 100 \text {. }
$$

W celu porównania akumulacji Ni przez badane rośliny wyliczono współczynnik bioakumulacji w częściach nadziemnych $\left(\mathrm{BF}_{\mathrm{nad}}\right)$ oraz współczynnik bioakumulacji w częściach podziemnych $\left(\mathrm{BF}_{\mathrm{pod}}\right)$. Do porównania translokacji $\mathrm{Ni}$ z części podziemnych do nadziemnych wyliczono współczynnik translokacji (TF). Współczynniki wyrażono następującymi wzorami:

$$
\begin{aligned}
& \mathrm{BF}_{\text {nad }}=\frac{\text { koncentracja Ni w częściach nadziemnych }[\mathrm{mg} / \mathrm{kg}]}{\text { koncentracja Ni w glebie }[\mathrm{mg} / \mathrm{kg}]}, \\
& \mathrm{BF}_{\mathrm{pod}}=\frac{\text { koncentracja Ni w częściach podziemnych }[\mathrm{mg} / \mathrm{kg}]}{\text { koncentracja Ni w glebie }[\mathrm{mg} / \mathrm{kg}]},
\end{aligned}
$$

$\mathrm{TF}=\frac{\text { koncentracja } \mathrm{Ni} \text { w częściach nadziemnych }[\mathrm{mg} / \mathrm{kg}]}{\text { koncentracja Ni w częściach podziemnych }[\mathrm{mg} / \mathrm{kg}]}$

\section{Analizy chemiczne}

Węgiel organiczny w glebie $\left(\mathrm{C}_{\text {org }}\right)$ oznaczano metodą Tiurina przy użyciu dwuchromianu potasu (PN-ISO14235: :2003), pH potencjometrycznie w $1 \mathrm{M} \mathrm{KCl}$ (ISO10390: :2005), P i K metodą Engera-Riehma (odpowiednio PN-R-04023:1996 i PN-R-04022:1996), Mg metodą Schachtschabela (PN-R-04020:1994), skład metryczny metodą areometryczną (PN-R-04033:1998), a Ni metodą FAAS, po roztworzeniu w wodzie królewskiej.

Nikiel w materiale roślinnym (naważka $5 \mathrm{~g}$ ) oznaczano metodą FAAS, po mineralizacji na sucho w piecu muflowym i roztworzeniu 20\% kwasem azotowym (PN-R-04014:1991). Do kontroli jakości analiz użyto materiału referencyjnego IPE 952 (International Plant-Analytical Exchange) z Wageningen.

Wszystkie analizy chemiczne wykonano w Głównym Laboratorium Analiz Chemicznych IUNG - PIB posiadającym certyfikat Polskiego Centrum Akredytacji (nr AB 339) zgodnie z PN-EN ISO/IEC 17025:2005.

\section{Obliczenia statystyczne}

Wszystkie wyniki dotyczące plonów roślin oraz zawartości $\mathrm{Ni}$ w glebie i roślinach podano jako średnie z 4 powtórzeń. Dla plonów wyliczono jednoczynnikową analizę wariancji przy wykorzystaniu programu AWAR opracowanego w Instytucie Uprawy Nawożenia i Gleboznawstwa (Filipiak i Wilkos 1995). Różnice pomiędzy średnimi testowano przy użyciu testu Tukeya $(\mathrm{p}<0,05)$.

\section{Wyniki i dyskusja / Results and discussion}

\section{Zawartość Ni w glebie}

Zawartość Ni w glebie po zbiorze roślin utrzymywała się na podobnym poziomie w obu sezonach wegetacyjnych (tab. 2). Średnia zawartość tego metalu na obiekcie $\mathrm{Ni}_{1}$ 
Tabela 2. Całkowita zawartość Ni w glebie po zbiorach $[\mathrm{mg} / \mathrm{kg}]$

Table 2. Total Ni concentration in soil after harvest $[\mathrm{mg} / \mathrm{kg}]$

\begin{tabular}{|c|c|c|c|c|c|}
\hline \multirow{2}{*}{$\begin{array}{l}\text { Roślina } \\
\text { Plant }\end{array}$} & \multirow{2}{*}{$\begin{array}{c}\text { Obiekt } \\
\text { Treatment }\end{array}$} & \multicolumn{2}{|c|}{ Rok - Year } & \multirow{2}{*}{$\begin{array}{c}\text { Średnia } \\
\text { Mean }\end{array}$} & \multirow{2}{*}{$\begin{array}{l}\text { Poziom zanieczyszczenia }^{1} \\
\text { Contamination level }^{1}\end{array}$} \\
\hline & & 2009 & 2010 & & \\
\hline $\begin{array}{l}\text { Miskant } \\
\text { Miscanthus } \times \text { giganteus }\end{array}$ & $\begin{array}{c}0 \\
\mathrm{Ni}_{1} \\
\mathrm{Ni}_{2} \\
\mathrm{Ni}_{3}\end{array}$ & $\begin{array}{c}7 \\
100 \\
163 \\
256 \\
\end{array}$ & $\begin{array}{c}8 \\
107 \\
154 \\
274 \\
\end{array}$ & $\begin{array}{c}8 \mathrm{a} \\
104 \mathrm{~b} \\
159 \mathrm{c} \\
265 \mathrm{~d}\end{array}$ & $\begin{array}{c}0 \\
\text { III/IV } \\
\text { IV } \\
\text { IV }\end{array}$ \\
\hline $\begin{array}{l}\text { Spartina } \\
\text { Spartina pectinata }\end{array}$ & $\begin{array}{c}0 \\
\mathrm{Ni}_{1} \\
\mathrm{Ni}_{2} \\
\mathrm{Ni}_{3}\end{array}$ & $\begin{array}{c}7 \\
106 \\
147 \\
291\end{array}$ & $\begin{array}{c}8 \\
82 \\
126 \\
256 \\
\end{array}$ & $\begin{array}{c}8 \mathrm{a} \\
94 \mathrm{~b} \\
137 \mathrm{c} \\
274 \mathrm{~d}\end{array}$ & $\begin{array}{l}0 \\
\text { III } \\
\text { IV } \\
\text { IV }\end{array}$ \\
\hline $\begin{array}{l}\text { Topinambur } \\
\text { Helianthus tuberosus }\end{array}$ & $\begin{array}{c}0 \\
\mathrm{Ni}_{1} \\
\mathrm{Ni}_{2} \\
\mathrm{Ni}_{3}\end{array}$ & $\begin{array}{c}6 \\
91 \\
176 \\
316\end{array}$ & $\begin{array}{c}6 \\
90 \\
172 \\
322\end{array}$ & $\begin{array}{c}6 \mathrm{a} \\
90 \mathrm{~b} \\
174 \mathrm{c} \\
319 \mathrm{~d}\end{array}$ & $\begin{array}{l}0 \\
\text { III } \\
\text { IV } \\
\text { IV }\end{array}$ \\
\hline
\end{tabular}

${ }^{1}$ według Kabaty-Pendias i wsp. (1993). Różne litery w ramach jednego gatunku wskazują na istotne różnice według testu Tukeya (p < 0,05)

${ }^{1}$ according Kabata-Pendias et al. (1993). Different letters within one species indicate significant differences according to Tukey's test (p < 0.05)

wahała się w granicach $90-104 \mathrm{mg} / \mathrm{kg}$, na $\mathrm{Ni}_{2}$ w granicach 137-174 mg/kg, a na $\mathrm{Ni}_{3} \mathrm{w}$ granicach $265-319 \mathrm{mg} / \mathrm{kg}$, zależnie od gatunku rośliny. Zawartości te odpowiadały średniemu i silnemu zanieczyszczeniu zgodnie z limitami zanieczyszczenia gleby metalami ciężkimi według Kabaty-Pendias i wsp. (1993) (tab. 3). Według polskich standardów (Rozporządzenie 2016) całkowita zawartość Ni w glebie na terenach rolniczych nie powinna przekraczać $100 \mathrm{mg} / \mathrm{kg}$, co pokrywa się z górną granicą średniego zanieczyszczenia gleby Ni według Kabaty-Pendias i wsp. (1993). W niniejszych badaniach zawartość Ni na obiektach $\mathrm{N}_{2}$ i $\mathrm{N}_{3}$ przekraczała dopuszczalny limit.

Tabela 3. Ocena zanieczyszczenia niklem lekkiej gleby piaskowej według Kabaty-Pendias i wsp. (1993) ${ }^{1}$

Table 3. Nickel contamination assessment of light sandy soil according Kabata-Pendias et al. (1993) ${ }^{1}$

\begin{tabular}{lc}
\hline $\begin{array}{l}\text { Stopień zanieczyszczenia } \\
\text { Contamination level }\end{array}$ & $\begin{array}{c}\mathrm{Ni} \\
{[\mathrm{mg} / \mathrm{kg}]}\end{array}$ \\
\hline $\begin{array}{l}\text { 0 - zawartość naturalna } \\
0 \text { - background content }\end{array}$ & $<10$ \\
\hline $\begin{array}{l}\text { I - zawartość podwyższona } \\
\text { I - increased content }\end{array}$ & $11-30$ \\
\hline $\begin{array}{l}\text { II - słabe zanieczyszczenie } \\
\text { II - weak contamination }\end{array}$ & $31-50$ \\
\hline $\begin{array}{l}\text { III - średnie zanieczyszczenie } \\
\text { III - medium contamination }\end{array}$ & $51-100$ \\
\hline $\begin{array}{l}\text { IV - silne zanieczyszczenie } \\
\text { IV - heavy contamination }\end{array}$ & $101-400$ \\
\hline V - bardzo silne zanieczyszczenie & $>400$ \\
V - very heavy contamination &
\end{tabular}

${ }^{1}$ zawartość frakcji - content of soil fraction $<0,02 \mathrm{~mm}: 10-20 \%$, $\mathrm{pH}<5,5$

\section{Plony roślin}

Fitotoksyczność Ni, objawiająca się obniżeniem plonów biomasy, była różna w zależności od gatunku rośliny i poziomu skażenia gleby tym metalem. Rośliny reagowały na Ni zarówno ograniczeniem biomasy części nadziemnych, jak i podziemnych (tab. 4).

Biomasa części nadziemnych wszystkich badanych gatunków obniżała się w stosunku do kontroli wraz ze wzrostem zawartości Ni w glebie, co obserwowano w obu latach badań (tab. 4). Największą redukcję biomasy części nadziemnych stwierdzono dla miskanta. Średnia z obu lat badań biomasa tej rośliny obniżyła się istotnie o $36 \%, 66 \%$ i $94 \%$ odpowiednio na $\mathrm{Ni}_{1}, \mathrm{Ni}_{2}$ i Ni 3 (rys. 1). Nieco mniejszy spadek biomasy części nadziemnych zaobserwowano dla topinamburu, gdzie wynosił on odpowiednio $23 \%, 52 \%$ i $91 \%$. Spartina charakteryzowała się wyraźnie mniejszą wrażliwością na wysoką koncentrację $\mathrm{Ni}$ w glebie niż miskant $\mathrm{i}$ topinambur. Istotna redukcja biomasy części nadziemnych tej rośliny wystąpiła jedynie na $\mathrm{Ni}_{2}$ i $\mathrm{Ni}_{3}$ i wynosiła odpowiednio 14\% i 75\%.

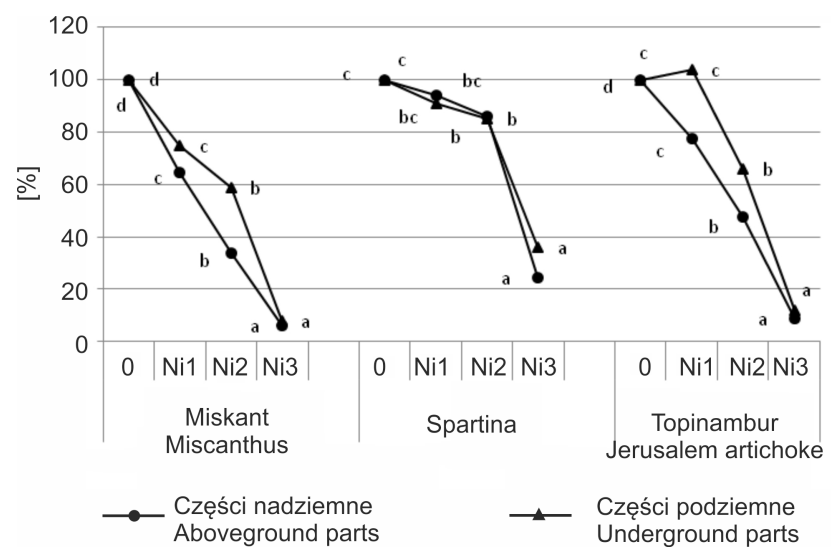

Rys. 1. Plon względny roślin doświadczalnych: średnia z lat 2009 i 2010 dla części nadziemnych i 2010 rok dla części podziemnych. Te same litery w ramach jednego gatunku i części rośliny wskazują na brak istotnych różnic według testu Tukeya $(\mathrm{p}<0,05)$

Fig. 1. Relative yield of tested plants: 2009-2010 mean for aboveground parts and 2010 year for underground parts. Same letters for each species-plant part combination indicate the lack of significant differences according to Tukey's test $(\mathrm{p}<0.05)$ 
Tabela 4. Plon roślin doświadczalnych $\left[\mathrm{g} / \mathrm{m}^{2}\right]$

Table 4. Yield of experimental plants $\left[\mathrm{g} / \mathrm{m}^{2}\right]$

\begin{tabular}{|c|c|c|c|c|}
\hline $\begin{array}{l}\text { Roślina } \\
\text { Plant }\end{array}$ & $\begin{array}{l}\text { Obiekt } \\
\text { Treatment }\end{array}$ & 2009 & \multicolumn{2}{|c|}{2010} \\
\hline \multirow{5}{*}{$\begin{array}{l}\text { Miskant } \\
\text { Miscanthus } \times \text { giganteus }\end{array}$} & & $\begin{array}{l}\text { części nadziemne }^{1} \\
\text { aboveground parts }\end{array}$ & $\begin{array}{l}\text { części nadziemne }^{2} \\
\text { aboveground parts }\end{array}$ & $\begin{array}{l}\text { korzenie } \\
\text { roots }\end{array}$ \\
\hline & 0 & $167 \mathrm{~d}$ & $457 \mathrm{~d}$ & 490 c \\
\hline & $\mathrm{Ni}_{1}$ & $96 \mathrm{c}$ & 325 c & $366 b$ \\
\hline & $\mathrm{Ni}_{2}$ & $49 \mathrm{~b}$ & $176 \mathrm{~b}$ & $288 \mathrm{~b}$ \\
\hline & $\mathrm{Ni}_{3}$ & $10 \mathrm{a}$ & $28 \mathrm{a}$ & 39 a \\
\hline \multirow{5}{*}{$\begin{array}{l}\text { Spartina } \\
\text { Spartina pectinata }\end{array}$} & & $\begin{array}{l}\text { części nadziemne }^{1} \\
\text { aboveground parts }\end{array}$ & $\begin{array}{l}\text { części nadziemne }^{2} \\
\text { aboveground parts }\end{array}$ & $\begin{array}{l}\text { korzenie } \\
\text { roots }\end{array}$ \\
\hline & 0 & $508 c$ & $1496 \mathrm{c}$ & $987 \mathrm{~b}$ \\
\hline & $\mathrm{Ni}_{1}$ & $477 \mathrm{c}$ & 1404 bc & 898 bc \\
\hline & $\mathrm{Ni}_{2}$ & $432 \mathrm{~b}$ & 1304 b & $840 \mathrm{~b}$ \\
\hline & $\mathrm{Ni}_{3}$ & $110 \mathrm{a}$ & 411 a & 357 a \\
\hline \multirow{5}{*}{$\begin{array}{l}\text { Topinambur } \\
\text { Helianthus tuberosus }\end{array}$} & & 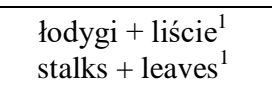 & $\begin{array}{l}\text { łodygi + liście } \\
\text { stalks }^{2} \\
\text { leaves }\end{array}$ & $\begin{array}{l}\text { bulwy } \\
\text { tubers }\end{array}$ \\
\hline & 0 & $883 \mathrm{~d}$ & $1341 \mathrm{~d}$ & 278 c \\
\hline & $\mathrm{Ni}_{1}$ & $727 \mathrm{c}$ & 972 c & 289 c \\
\hline & $\mathrm{Ni}_{2}$ & $462 \mathrm{~b}$ & $575 b$ & $185 b$ \\
\hline & $\mathrm{Ni}_{3}$ & 85 a & 107 a & 33 a \\
\hline
\end{tabular}

${ }^{1}$ jeden pokos, ${ }^{2}$ suma dwóch pokosów. Te same litery w ramach jednego gatunku i kombinacji rok-część rośliny wskazują na brak istotnych różnic według testu Tukeya $(\mathrm{p}<0,05)$

${ }^{1}$ one cut, ${ }^{2}$ sum of two cuts. The same letters for each plant organ-year combination indicate the lack of significant differences according to Tukey's test $(\mathrm{p}<0.05)$

Tabela 5. Indeks tolerancji (TI) [\%]

Table 5. Tolerance index (TI) [\%]

\begin{tabular}{l|c|c|c}
\hline \multirow{2}{*}{ Roślina - Plant } & 2009 & \multicolumn{2}{|c}{2010} \\
\cline { 2 - 4 } & $\begin{array}{c}\text { części nadziemne } \\
\text { aboveground parts }\end{array}$ & $\begin{array}{c}\text { części nadziemne } \\
\text { aboveground parts }\end{array}$ & $\begin{array}{c}\text { części podziemne } \\
\text { underground parts }\end{array}$ \\
\hline Miskant - Miscanthus $\times$ giganteus & 31 & 39 & 47 \\
Spartina - Spartina pectinata & 67 & 70 & 71 \\
Topinambur - Helianthus tuberosus & 48 & 41 & 61 \\
\hline
\end{tabular}

Dla wszystkich badanych roślin spadek biomasy części podziemnych był nieco mniejszy niż nadziemnych. Największą redukcję, podobnie jak w przypadku części nadziemnych, odnotowano dla miskanta. Biomasa korzeni tej rośliny obniżyła się istotnie o $25 \%$ na $\mathrm{Ni}_{1}, 41 \%$ na $\mathrm{Ni}_{2}$ i o $92 \%$ na $\mathrm{Ni}_{3}$ w stosunku do kontroli. Wpływ $\mathrm{Ni}$ na ograniczenie wzrostu korzeni miskanta potwierdzają inni autorzy, którzy w warunkach hydroponiki stwierdzili, że Ni zakumulowany w korzeniach tej rośliny ograniczał ich rozgałęzianie (Seregin i wsp. 2003) oraz długość (Maksimovic i wsp. 2007). Mniejszą niż u miskanta redukcję biomasy części podziemnych zaobserwowano $\mathrm{u}$ topinamburu, a najmniejszą $\mathrm{u}$ spartiny. Negatywną reakcję tych gatunków na $\mathrm{Ni}$ stwierdzono jedynie na obiektach $\mathrm{Ni}_{2}$ i $\mathrm{Ni}_{3}$ (odpowiednio 34\% i 88\% oraz $15 \%$ i 64\%) (rys. 1).

O większej tolerancji spartiny niż pozostałych badanych roślin na $\mathrm{Ni}$ w glebie świadczą wyliczone indeksy tolerancji (TI). Wynosiły one dla tego gatunku aż 67-71\%, podczas gdy dla topinamburu 41-61\%, a dla miskanta jedynie 31-47\% (tab. 5).

Dużą tolerancję rodzaju Spartina na metale ciężkie potwierdzają inni autorzy. Redondo-Gómez (2013) podaje, że tolerancja metali przez trawy z tego rodzaju związana jest $\mathrm{z}$ wykorzystaniem przez rośliny kilku mechanizmów tolerancji, takich jak chelatowanie metali, usuwanie ich z wnętrza komórki oraz sekwestracja w wakuolach i ścianach komórkowych. Literatura dotycząca plonowania rodzaju Miscanthus i Spartina na glebach zanieczyszczonych metalami ciężkimi jest dość bogata, ale najczęściej dotyczy innych gatunków niż Miscanthus $\times$ giganteus i Spartina pecinata.

\section{Zawartość Ni w roślinach}

Zawartość Ni w częściach nadziemnych roślin zależała od poziomu zawartości tego metalu w glebie, gatunku rośliny, a także jej wieku, co wiąże się z długością okresu uprawy (1 rok lub 2 lata). W pierwszym roku (2009), 
w miskancie koncentracja $\mathrm{Ni}$ wahała się $\mathrm{w}$ granicach 7,6-54,1, w spartinie 5,5-39,4, a w topinamburze w zakresie $8,1-20,5 \mathrm{mg} / \mathrm{kg}$ (tab. 6). Na najwyższym poziomie zanieczyszczenia gleby niklem $\left(\mathrm{Ni}_{3}\right)$ u miskanta i spartiny stwierdzono około 100-krotny wzrost koncentracji Ni w częściach nadziemnych, podczas gdy u topinamburu wykazano tylko 15-krotny wzrost koncentracji tego metalu w porównaniu z obiektem kontrolnym (0).

W drugim roku uprawy (2010) poziom zawartości Ni w częściach nadziemnych miskanta i spartiny znacznie się zmniejszył w porównaniu z rokiem 2009. Przy niższych poziomach skażenia $\left(\mathrm{Ni}_{1} \mathrm{i} \mathrm{Ni}_{2}\right)$ zawartość tego metalu w częściach nadziemnych wymienionych gatunków zmniejszyła się o 10-38\%, natomiast przy poziomie $\mathrm{Ni}_{3}$ w przypadku miskanta aż o $77 \%$, a w przypadku spartiny o $65 \%$. Inaczej na nadmiar $\mathrm{Ni}$ w glebie reagował topinambur. W porównaniu $\mathrm{z}$ pierwszym rokiem uprawy, w drugim roku nastąpił wzrost zawartości Ni w jego częściach nadziemnych o 26-51\% w zależności od poziomu zawartości Ni w glebie.

Zmniejszenie się zawartości Ni w miskancie i spartinie w drugim roku uprawy mogło być związane $\mathrm{z}$ wiekiem

Tabela 6. Zawartość niklu w roślinach [mg/kg]

Table 6. Nickel concentration in plants $[\mathrm{mg} / \mathrm{kg}]$

\begin{tabular}{|c|c|c|c|c|}
\hline Roślina - Plant & Obiekt - Treatment & 2009 & \multicolumn{2}{|c|}{2010} \\
\hline \multirow{5}{*}{$\begin{array}{l}\text { Miskant } \\
\text { Miscanthus } \times \text { giganteus }\end{array}$} & & $\begin{array}{l}\text { części nadziemne } \\
\text { aboveground parts }\end{array}$ & $\begin{array}{l}\text { części nadziemne }^{1} \\
\text { aboveground parts }\end{array}$ & $\begin{array}{l}\text { korzenie } \\
\text { roots }\end{array}$ \\
\hline & 0 & $0,5 \mathrm{a}$ & $0,5 \mathrm{a}$ & 4,7 a \\
\hline & $\mathrm{Ni}_{1}$ & $7,6 \mathrm{~b}$ & $4,9 \mathrm{~b}$ & $34,6 \mathrm{~b}$ \\
\hline & $\mathrm{Ni}_{2}$ & 9,4 c & $6,8 \mathrm{c}$ & 40,3 c \\
\hline & $\mathrm{Ni}_{3}$ & $54,1 \mathrm{~d}$ & $12,5 \mathrm{~d}$ & $52,9 \mathrm{~d}$ \\
\hline \multirow{5}{*}{$\begin{array}{l}\text { Spartina } \\
\text { Spartina pectinata }\end{array}$} & & $\begin{array}{l}\text { części nadziemne } \\
\text { aboveground parts }\end{array}$ & $\begin{array}{l}\text { części nadziemne }^{1} \\
\text { aboveground parts }^{1}\end{array}$ & $\begin{array}{l}\text { korzenie } \\
\text { roots }\end{array}$ \\
\hline & 0 & $0,4 \mathrm{a}$ & $0,9 \mathrm{a}$ & 2,3 a \\
\hline & $\mathrm{Ni}_{1}$ & $5,5 \mathrm{~b}$ & $5,0 \mathrm{~b}$ & $33,8 \mathrm{~b}$ \\
\hline & $\mathrm{Ni}_{2}$ & $11,2 \mathrm{c}$ & $6,9 \mathrm{c}$ & 73,6 c \\
\hline & $\mathrm{Ni}_{3}$ & $39,4 \mathrm{~d}$ & $13,7 \mathrm{~d}$ & $126,0 \mathrm{~d}$ \\
\hline \multirow{5}{*}{$\begin{array}{l}\text { Topinambur } \\
\text { Helianthus tuberosus }\end{array}$} & & $\begin{array}{l}\text { łodygi z liśćmi } \\
\text { stalks with leaves }\end{array}$ & $\begin{array}{l}\text { łodygi z liśćmi }{ }^{1} \\
\text { stalks with leaves }\end{array}$ & $\begin{array}{l}\text { bulwy } \\
\text { tubers }\end{array}$ \\
\hline & 0 & $1,41 \mathrm{a}$ & 2,07 a & $1,55 \mathrm{a}$ \\
\hline & $\mathrm{Ni}_{1}$ & $8,14 b$ & $12,3 \mathrm{~b}$ & $27,6 \mathrm{~b}$ \\
\hline & $\mathrm{Ni}_{2}$ & $10,0 \mathrm{c}$ & $12,8 \mathrm{~b}$ & $32,8 \mathrm{c}$ \\
\hline & $\mathrm{Ni}_{3}$ & $20,5 \mathrm{~d}$ & $25,8 \mathrm{c}$ & $33,0 \mathrm{c}$ \\
\hline
\end{tabular}

${ }^{1}$ średnia z dwóch pokosów. Te same litery w ramach jednego gatunku i kombinacji rok-część rośliny wskazują na brak istotnych różnic według testu Tukeya $(\mathrm{p}<0,05)$

${ }^{1}$ mean over two cuts. The same letters for each plant organ-year combination indicate the lack of significant differences according to Tukey's test $(\mathrm{p}<0.05)$

Tabela 7. Współczynnik bioakumulacji (BF) i translokacji (TF)

Table 7. Bioaccumulation (BF) and translocation factor (TF)

\begin{tabular}{l|c|c|c|c|c}
\hline \multicolumn{1}{c|}{ Roślina - Plant } & Obiekt - Treatment & $\mathrm{BF}_{\text {nad }}{ }^{1}-2009$ & $\mathrm{BF}_{\text {nad }}-2010^{2}$ & $\mathrm{BF}_{\text {pod }}{ }^{3}-2010$ & $\mathrm{TF}-2010$ \\
\hline \multirow{3}{*}{ Miskant } & $\mathrm{Ni}_{1}$ & 0,08 & 0,05 & 0,32 & 0,14 \\
Miscanthus $\times$ & $\mathrm{Ni}_{2}$ & 0,06 & 0,04 & 0,26 & 0,17 \\
giganteus & $\mathrm{Ni}_{3}$ & 0,21 & 0,05 & 0,19 & 0,24 \\
& średnia - mean & 0,11 & 0,05 & 0,26 & 0,18 \\
Spartina & $\mathrm{Ni}_{1}$ & 0,05 & 0,06 & 0,41 & 0,15 \\
Spartina pectinata & $\mathrm{Ni}_{2}$ & 0,08 & 0,05 & 0,58 & 0,09 \\
& $\mathrm{Ni}_{3}$ & 0,14 & 0,05 & 0,49 & 0,11 \\
Topinambur & średnia-mean & 0,09 & 0,06 & 0,50 & 0,12 \\
Helianthus tuberosus & $\mathrm{Ni}_{1}$ & 0,09 & 0,14 & 0,31 & 0,45 \\
& $\mathrm{Ni}_{2}$ & 0,06 & 0,07 & 0,19 & 0,39 \\
\hline
\end{tabular}

${ }^{1}$ nad - część nadziemna - aboveground parts, ${ }^{2}$ średnia z dwóch pokosów - mean over two cuts, ${ }^{3}$ pod - część podziemna (korzenie lub bulwy) - underground part (roots or tubers) 
roślin i wielkością korzeni. Można założyć, że w drugim sezonie wegetacji, korzenie miskanta dotarły do głębszej warstwy gleby, która była nieskażona, co spowodowało zmniejszenie koncentracji Ni w biomasie części nadziemnej. W przeprowadzonym doświadczeniu Ni został wprowadzony do gleby w warstwie 0-30 cm, a korzenie miskanta, 7 miesięcy po posadzeniu, mogą osiągnąć długość 1,5-2,0 m (Mann i wsp. 2013). W spartinie stwierdzono nieco mniejszy spadek koncentracji Ni w porównaniu z miskantem. Korzenie spartiny, w drugim roku po posadzeniu, osiągają długość $40 \mathrm{~cm}$ (USDA, NRCS 2014).

Zawartości Ni w częściach podziemnych roślin doświadczalnych analizowano jedynie w drugim roku badań. U obu gatunków traw w części podziemnej, którą stanowiły korzenie, zawartość Ni wzrastała w miarę wzrostu poziomu skażenia gleby, przy czym była ona od kilku do kilkunastu razy większa $\mathrm{w}$ porównaniu $\mathrm{z}$ częścią nadziemną tych traw (tab. 6). Największą zawartość $\mathrm{Ni}$ stwierdzono w korzeniach spartiny, która w zależności od poziomu skażenia gleby wahała się $\mathrm{W}$ granicach 33,8-126,0 $\mathrm{mg} / \mathrm{kg}$ i była 7-11 razy większa niż w częściach nadziemnych. W pracy przeglądowej Redondo-Gómez (2013) dotyczącej bioakumulacji metali ciężkich przez gatunki z rodzaju Spartina, autorka donosi, że większość $\mathrm{z}$ nich charakteryzuje się zwiększoną koncentracją metali w korzeniach, w stosunku do części nadziemnych, nie przedstawia jednak badań odnośnie zawartości Ni w S. pectinata. Cambrolle i wsp. (2011) stwierdzili w warunkach naturalnego skażenia gleb $\mathrm{Co}, \mathrm{Cr}$ i $\mathrm{Ni}$, że zawartość $\mathrm{Ni}$ w korzeniach $S$. densiflira i S. maritima wahała się od 6,5 do $15,6 \mathrm{mg} / \mathrm{kg}$, a w częściach nadziemnych od 0,5 do $5,0 \mathrm{mg} / \mathrm{kg}$, co stanowi kilkukrotnie mniejszą zawartość w porównaniu z korzeniami.

Korzenie miskanta w przeprowadzonych badaniach charakteryzowały się koncentracją $\mathrm{Ni}$ w zakresie 34,6-52,9 mg/kg, co było 4-7-krotnie większą zawartością $\mathrm{W}$ porównaniu $\mathrm{z}$ częścią nadziemną, podczas gdy w badaniach wazonowych Fernando i Oliveira (2004) korzenie miskanta nie wykazywały większych zawartości Ni niż pędy.

W części podziemnej topinamburu, którą stanowiły bulwy, zawartość Ni była 2-3-krotnie wyższa niż w części nadziemnej, a zakres wahań, w zależności od stopnia skażenia gleby, był bardzo niewielki $(27,6-33,0 \mathrm{mg} / \mathrm{kg})$. Znacznie większe zawartości $\mathrm{Ni}$ w bulwach topinamburu (128-169 mg/kg) wykazały badania Willscher i wsp. (2017), przy porównywalnym poziomie zawartości $\mathrm{Ni}$ w glebie, jak w przeprowadzonym doświadczeniu (100 mg/kg). Autorzy cytowani powyżej przeprowadzili badania w wazonach, w warunkach łącznego skażenia gleby 7 metalami, w tym Ni. Pobieranie Ni przez topinambur mogło być $\mathrm{w}$ tym przypadku modyfikowane interakcjami zachodzącymi pomiędzy poszczególnymi metalami, jak również specyficznymi warunkami pobierania metali z gleby związanymi z jej ograniczoną objętością w wazonie.

\section{Akumulacja i translokacja Ni w roślinach}

Akumulacja Ni w badanych roślinach zachodziła głównie w częściach podziemnych (korzenie lub bulwy), przy czym miskant i topinambur gromadził $\mathrm{Ni}$ w podobnym stopniu, spartina natomiast wyróżniała się większą zdolnością akumulacji tego pierwiastka w korzeniach, niż pozostałe gatunki (tab. 7). Średnie współczynniki bioakumulacji $\left(\mathrm{BF}_{\mathrm{pod}}\right)$, wyliczone jako średnie dla wszystkich stopni skażenia gleby $\mathrm{Ni}$, wynosiły odpowiednio 0,26 i 0,20 dla miskanta i topinamburu oraz 0,50 dla spartiny.

W częściach nadziemnych wszystkie testowane rośliny wykazywały podobny, bardzo niewielki poziom akumulacji Ni, który w pierwszym roku uprawy nie przekraczał wartości $\mathrm{BF}_{\text {nad }}=0,11$ (miskant), a w drugim roku wartości $\mathrm{BF}_{\text {nad }}=0,10$ (topinambur). Wszystkie współczynniki BF ${ }_{\text {nad }}$ były znacznie niższe od wartości 1,0 , co wskazuje na całkowity brak przydatności badanych roślin do fitoekstrakcji metalu z gleby (McGrath i Zhao 2003).

Niskie współczynniki bioakumulacji Ni w częściach nadziemnych były konsekwencją określonego systemu dystrybucji tego metalu w roślinie. Transport Ni z części podziemnych do nadziemnych był $\mathrm{w}$ pewnym stopniu hamowany wskutek uruchomienia mechanizmów obronnych przed stresem wynikającym z nadmiaru Ni w glebie. Wartości współczynników translokacji kształtowały się na poziomie $\mathrm{TF}<1$, przy czym dla obu gatunków traw, a zwłaszcza dla spartiny, były one znacznie niższe niż dla topinamburu (tab. 7). Średni dla 3 poziomów skażenia gleby współczynnik TF wynosił 0,12 dla spartiny, 0,18 dla miskanta i 0,54 dla topinamburu. Oznacza to, że spartina transferowała do części nadziemnych tylko $12 \%$ Ni zawartego w korzeniach, natomiast topinambur aż 54\%.

\section{Wnioski / Conclusions}

1. Żaden $\mathrm{z}$ badanych gatunków nie nadawał się do fitoekstrakcji Ni z gleby $\mathrm{z}$ powodu zbyt niskich wartości współczynnika bioakumulacji dla części nadziemnych $\left(\mathrm{BF}_{\text {nad }}=0,05-0,11\right)$. Gatunki odpowiednie do tego rodzaju remediacji gleby powinny charakteryzować się $\mathrm{BF}_{\text {nad }}>1$.

2. Badane rośliny nie wykazały wysokiego potencjału fitostabilizacyjnego w stosunku do gleby skażonej $\mathrm{Ni}$, ponieważ nie zostało spełnione kryterium zdolności gromadzenia metalu w częściach podziemnych na odpowiednim poziomie $\left(\mathrm{BF}_{\text {pod }}>1\right)$.

3. Ograniczenie transportu $\mathrm{Ni}$ z części podziemnej do nadziemnej, co jest drugim warunkiem przydatności roślin do fitostabilizacji, spełniały wszystkie trzy gatunki, przy czym najniższy współczynnik translokacji Ni stwierdzono dla spartiny $(\mathrm{TF}=0,12)$. Parametr ten kształtował się na dużo niższym poziomie, niż wymagana wartość progowa $(\mathrm{TF}<1)$.

4. Spośród badanych gatunków roślin spartina wykazała najwyższą tolerancję na $\mathrm{Ni}(70 \%)$ oraz stosunkowo dużą zdolność akumulacji Ni w korzeniach $\left(\mathrm{BF}_{\text {pod }}=\right.$ $0,50) \mathrm{W}$ porównaniu $\mathrm{z}$ miskantem $\left(\mathrm{BF}_{\text {pod }}=0,26\right)$ i topinamburem $\left.\mathrm{BF}_{\text {pod }}=0,20\right)$. Ponadto gatunek ten charakteryzował się dużą masą korzeniową, co jest korzystne w ograniczaniu erozji gleby i rozprzestrzenianiu się Ni w środowisku. Wydaje się, że spartina może być skutecznie wykorzystywana do fitostabilizacji gleby skażonej $\mathrm{Ni}$, pomimo że nie spełniała warunku $\mathrm{BF}_{\text {pod }}>1$. 


\section{Literatura / References}

Adamo P., Dudka S., Wilson M.J., McHardy W.J. 2002. Distribution of trace elements in soils from the Sudbury smelting area (Ontario, Canada). Water, Air, and Soil Pollution 137 (1-4): 95-116. DOI: 10.1023/A:1015587030426.

Ahmad M.S.A., Ashraf M. 2011. Essential roles and hazardous effects of nickel in plants. p. 125-167. In: "Reviews of Environmental Contamination and Toxicology” (D.M. Whitacre, eds.). Springer International Publishing, 214 pp. DOI: 10.1007/978-1-4614-0668-6_6.

Al Chami Z., Amer N., Al Bitar L., Cavoski I. 2015. Potential use of Sorghum bicolor and Carthamus tinctorius in phytoremediation of nickel, lead and zinc. International Journal of Environmental Science and Technology 12: 3957-3970. DOI: 10.1007/s13762-015$-0823-0$.

Algreen M., Trapp S., Rein A. 2014. Phytoscreening and phytoextraction of heavy metals at Danish polluted sites using willow and poplar trees. Environmental Science and Pollution Research 21 (15): 8992-9001. DOI: 10.1007/s11356-013-2085-z.

Ali M.B., Vajpayee P., Tripathi R.D., Rai U.N., Singh S.N., Singh S.P. 2003. Phytoremediation of lead, nickel, and copper by Salix acmophylla Boiss.: Role of antioxidant enzymes and antioxidant substances. Bulletin of Environmental Contamination and Toxicology 70: 462-469. DOI: 10.1007/s00128-003-0009-1.

Antonkiewicz J., Jasiewicz Cz., Koncewicz-Baran M., Sendor R. 2016. Nickel bioaccumulation by the chosen plant species. Acta Physiologiae Plantarum 38: 40-51. DOI: 10.1007/s11738-016-2062-5.

Bacon J.R., Dinev N.S. 2005. Isotopic characterisation of lead in contaminated soils from the vicinity of a non-ferrous metal smelter near Plovdiv, Bulgaria. Environmental Pollution 134: 247-255. DOI: 10.1016/j.envpol.2004.07.03.

Cambrolle J., Mateos-Naranjo E., Redondo-Gómez S., Luque T., Figueroa M.E. 2011. The role of two Spartina species in phytostabilization and bioaccumulation of $\mathrm{Co}, \mathrm{Cr}$, and Ni in the Tinto-Odiel estuary (SW Spain). Hydrobiologia 671: 95-103. DOI: 10.1007/s10750-011-0706-4.

Cheraghi M., Lorestani B., Khorasani N., Yousef N., Karami M. 2011. Findings on the phytoextraction and phytostabilization of soils contaminated with heavy metals. Biological Trace Element Research 144 (1-3): 1133-1141. DOI: 10.1007/s12011-009-8359-0.

Fernando A., Oliveira J.S. 2004. Effects on growth, productivity and biomass quality of Miscanthus $\times$ giganteus of soils contaminated with heavy metals. 2nd World Conference on Biomass for Energy, Industry and Climate Protection. Italy, Rome, 10-14 May 2004, http://moodle.fct.unl.pt/pluginfile.php/92027/mod_resource/content/0/Fernando_e_Oliveira_2004.pdf

Filipiak K., Wilkos S. 1995. Obliczenia statystyczne. Opis systemu AWAR. Wydawnictwo IUNG, Puławy, 52 ss.

Gaj R., Izosimova A., Shnug E. 2007. Organic fertilization effects on heavy metal uptake. p. 1169-1171. In: "Encyclopedia of Soil Science” Volume 2 (R. Lal, eds.). Taylor and Francis/CRC Press, Boca Raton, 2060 pp.

Ghosh M., Singh S.P. 2005. A review on phytoremediation of heavy metals and utilization of its by products. Applied Ecology and Environmental Research 3 (1): 1-18.

Golda S., Korzeniowska J. 2016. Comparison of phytoremediation potential of three grass species in soil contaminated with cadmium. Environmental Protection and Natural Resources 27 (1): 8-14. DOI: 10.1515/OSZN-2016-0003.

Kabata-Pendias A., Motowicka-Terelak T., Piotrowska M., Terelak H., Witek T. 1993. Ocena stopnia zanieczyszczenia gleb i roślin metalami ciężkimi i siarką. Ramowe wytyczne dla rolnictwa. Wydawnictwo IUNG, Puławy, P(53), 20 ss.

Kabata-Pendias A., Mukherjee A.B. 2007. Trace Elements from Soil to Human. Springer International Publishing, Berlin, Heidelberg, NewYork, 550 pp.

Kacálková L., Tlustoš P., Száková J. 2014. Chromium, nickel, cadmium, and lead accumulation in maize, sunflower, willow, and poplar. Polish Journal of Environmental Studies 23 (3): 753-761.

Karczewska A., Lewinska K., Gałka B. 2013. Arsenic extractability and uptake by velvetgrass Holcus lanatus and ryegrass Lolium perenne in variously treated soils polluted by tailing spills. Journal of Hazardous Materials 262 (15): 1014-1021. DOI: 10.1016/j.jhazmat.2012.09.008.

Maksimovic I., Kastori R., Krstic L., Lukovic J. 2007. Steady presence of cadmium and nickel affects root anatomy, accumulation and distribution of essential ions in maize seedlings. Biologia Plantarum 51 (3): 589-592.

Mann J.J., Barney J.N., Kyser G.B., DiTomaso J.M. 2013. Root system dynamics of Miscanthus $\times$ giganteus and Panicum virgatum in response to rained and irrigated conditions in California. BioEnergy Research 6 (2): 678-687. DOI: 10.1007/s12155-012-9287-y.

Masarovicova E., Kralova K., Kummerova M. 2010. Principles of classification of medical plants as hyperaccumulators or excluders. Acta Physiologiae Plantarum 32 (5): 823-829. DOI: 10.1007/s11738-010-0474-1.

McGrath S.P., Zhao F.J. 2003. Phytoextraction of metals and metalloids from contaminated soils. Current Opinion in Biotechnology 14 (3): 277-282.

Melo E.E.C., Costa E.T.S., Guilherme L.R.G., Faquin V., Nascimento C.W.A. 2009. Accumulation of arsenic and nutrients by castor bean plants grown on an As-enriched nutrient solution. Journal of Hazardous Materials 168 (1): 479-483. DOI: 10.1016/j.jhazmat. 2009.02.048.

Mulligan C.N., Yong R.N., Gibbs B.F. 2001. Remediation technologies for metal-contaminated soils and groundwater: an evaluation. Engineering Geology 60: 193-207. DOI: 10.1016/S0013-7952(00)00101-0.

Narendrula R., Nkongolo K.K., Beckett P. 2012. Comparative soil metal analyses in Sudbury (Ontario, Canada) and Lubumbashi (Katanga, DR-Congo). Bulletin of Environmental Contamination and Toxicology 88 (2): 187-192. DOI: 10.1007/s00128-011-0485-7.

Ngole V.M., Ekosse G.I.E. 2012. Copper, nickel and zinc contamination in soils within the precincts of mining and landfilling environments. International Journal of Environmental Science and Technology 9: 485-494. DOI: 10.1007/s13762-012-0055-5.

Raskin I., Ensley B.D. 2000. Phytoremediation of Toxic Metals: Using Plants to Clean Up the Environment. John Wiley \& Sons, New York, NY, USA, 304 pp.

Redondo-Gómez S. 2013. Bioaccumulation of heavy metals in Spartina. Functional Plant Biology 40 (9): 913-921. DOI: 10.1071/ /FP12271.

Roccotiello E., Manfredi A., Drava G., Minganti V., Mariotti M., Berta G., Cornara L. 2010. Zinc tolerance and accumulation in the ferns Polypodium cambricum L. and Pteris vittata L. Ecotoxicology and Environmental Safety 73: 1264-1271. DOI: 10.1016/ /j.ecoenv.2010.07.019.

Rozporządzenie Ministra Środowiska z dnia 1 września 2016 r. w sprawie sposobu prowadzenia oceny zanieczyszczenia powierzchni ziemi. Dz. U. 2016, poz. 1395. 
Seregin I.V., Kozhevnikova A.D., Kazyumina E.M., Ivanov V.B. 2003. Nickel toxicity and distribution in maize roots. Russian Journal of Plant Physiology 50 (5): 711-717. DOI: 10.1023/a:1025660712475.

Shafeeq A., Butt Z.A., Muhammad S. 2012. Response of nickel pollution on physiological and biochemical attributes of wheat (Triticum aestivum L.) var. Bhakar-02. Pakistan Journal of Botany 44 (1): 111-116.

Srivastava N. 2016. Phytoremediation of heavy metals contaminated soils through transgenic plants. p. 345-391. In: "Phytoremediation” (A.A. Ansari, S.S. Gill, R. Gill, G.R. Lanza, L. Newman, eds.). Springer International Publishing, 566 pp.

Stanislawska-Glubiak E., Korzeniowska J., Kocon A. 2012. Effect of the reclamation of heavy metal-contaminated soil on growth of energy willow. Polish Journal of Environmental Studies 21 (1): 187-192.

Stanislawska-Glubiak E., Korzeniowska J., Kocon A. 2015. Effect of peat on the accumulation and translocation of heavy metals by maize grown in contaminated soils. Environmental Science and Pollution Research 22 (6): 4706-4714. DOI: 10.1007/s11356-014-3706-X.

Thakur S., Singh L., Ab Wahid Z., Siddiqui M.F., Atnaw S.M., Din M.F.M. 2016. Plant-driven removal of heavy metals from soil: uptake, translocation, tolerance mechanism, challenges, and future perspectives. Environmental Monitoring and Assessment 188 (4): 1-11. DOI: 10.1007/s10661-016-5211-9.

Tokar E.J., Benbrahim-Tallaa L., Waalkes M.P. 2011. Metal ions in human cancer development. Metal Ions in Life Sciences 8: $375-401$.

Toth G., Hermann T., Da Silva M.R., Montanarella L. 2016. Heavy metals in agricultural soils of the European Union with implications for food safety. Environment International 88: 299-309. DOI: 10.1016/j.envint.2015.12.017.

USDA, NRCS. 2014. The PLANTS Database (http://plants.usda.gov, 30 October 2014). National Plant Data Team, Greensboro, NC 27401-4901 USA.

WHO. Regional Office for Europe 2000. Air Quality Guidelines: Second Edition. Copenhagen, Denmark, 273 pp.

Willscher S., Jablonski L., Fona Z., Rahmi R., Wittig J. 2017. Phytoremediation experiments with Helianthus tuberosus under different pH and heavy metal soil concentrations. Hydrometallurgy 168: 153-158. DOI: org/10.1016/j.hydromet.2016.10.016.

Yusuf M., Fariduddin Q., Hayat S., Ahmad A. 2011. Nickel: an overview of uptake, essentiality and toxicity in plants. Bulletin of Environmental Contamination and Toxicology 86 (1): 1-17. DOI: 10.1007/s00128-010-0171-1. 